Article

\title{
Fields of Action for Designing Measures to Avoid Food Losses in Logistics Networks
}

\author{
Julia Kleineidam(1) \\ Chair of Logistics, Institute for Technology and Management, Technical University of Berlin, 10623 Berlin, \\ Germany; kleineidam@logistik.tu-berlin.de; Tel.: +49-3031-426-747
}

Received: 23 June 2020; Accepted: 27 July 2020; Published: 29 July 2020

\begin{abstract}
The literature contains many analyses of measures against food loss. However, there exists no structured analysis of the objective of these measures. This study employs a systematic literature analysis and open expert interviews, combining the perspectives of science and practice. For each analyzed case, we identified the objectives behind the implemented measures. Using qualitative clustering, we categorized the located objectives into fields of action. The identified 13 fields of action provide an overview of the objectives of food loss prevention measures. The results indicate that different levels of importance can be assigned to these fields of action. In particular, the results show the relevance of increased network cooperation and transparency within a company and along the entire value chain. Furthermore, the study indicates that the creation of transparency provides the greatest overall added value in terms of reducing food losses.
\end{abstract}

Keywords: food loss management; food logistics; success factors; systematic literature review; interviews

\section{Introduction}

Overcoming the challenges in current food supply systems is crucial in providing enough food for a continuously growing world population. While resources for food production are limited, the Food and Agriculture Organization of the United Nations (FAO) estimates that approximately one-third of the food produced does not reach the consumer [1]. Lost food is not only a problem because it cannot be used to feed the people who need it, but also because it involves a considerable waste of resources [2]. Eliminating current food losses would be enough to meet the caloric requirements of 1.9 billion people at a time when, according to the United Nations (UN), about 815 million people worldwide are suffering from hunger [3]. Considering FAO statistics, it is evident that significant losses are occurring both on the consumer end and within the value chain [4]. Therefore, it is generally accepted that issues in the global food supply do not reflect a production problem but a distribution issue [5].

The food loss problem is not a new phenomenon. Though it has not been in the public spotlight for long, this topic has gained new momentum through various initiatives, resulting in its integration into the UN's 17 global sustainable development goals. The 12th sustainable development goal "responsible consumption" includes a sub-objective (12.3), stating that, by 2030, global food losses should be reduced by half throughout the entire food value chain, including post-harvest losses and the end consumer [6]. This objective directly addresses the core functions of logistics and supply chain management, thus representing a direct task for this area of industry and science.

In the current scientific literature, there are many reports on preventive strategies for food loss [7]. Some research deals with the appropriate use of technologies while other studies describe design processes that can reduce losses. However, the approaches described in the literature usually address a 
specific case study or relate to the properties of a particular food group. Despite promising results in their respective fields, these approaches can only be transferred to a limited number of other situations.

A more generally applicable solution could be formulated by considering the fields of action underlying the design of the measures described in the current literature. This study provides an overview of such fields of action, as reflected in the following research question:

RQ1: Which criteria are set as objective parameters when developing logistics measures against food losses?

In order to answer this research question, we first turn to defining key terms in the research before describing the methodology. We then describe the results of the analysis and discuss them in detail afterward.

\subsection{Food Logistics}

This paper begins by providing an overview of the terms "logistics" and "supply chain management." According to Straube (2004), the basic function of logistics is "[ ... ] the economical and on-time production, provision and delivery of goods, materials, products and services ordered by customers. Logistics organizes processes, system structures and entire networks from increasingly globally distributed origins to globally distributed destinations" [8] (p. 27). Though this definition covers logistics in a general manner, this paper refers to food logistics in particular, requiring greater specification. Based on this understanding of logistics, Straube, Nitsche, and Figiel (2016) further describe food logistics as follows: "Food logistics comprises the planning, management and control of the value-added network of food from the source of raw materials to the customer. The focus here is on the efficient processing of customer orders with the aid of information systems, technologies and management concepts, with special consideration of high article-specific quality and safety requirements for perishable goods in various temperature ranges" [9] (p. 6). This understanding of logistics is applied in this paper.

In accordance with this view, food logistics are applied along the entire food value chain. Various approaches in the current literature describe the design of a generic food value chain. The most common representations differ mainly in terms of the level of detail for each of the defined individual steps within the value chain. To illustrate, we can compare the concepts of Parfitt et al. (2010) and Gustavsson et al. (2011) as examples. Gustavsson et al. (2011) present a definition of the food value chain in five stages. Starting with agriculture, processes like threshing, fishing, or milk production form the first stage. The second stage of the chain involves post-harvest processing, which includes sorting, drying, and cleaning processes. Additionally, it includes handling and storage, transport to slaughter for meat products, icing and packaging for fish products, and transport between farm and distribution for dairy products. In the third step, the raw materials are then processed into higher-quality food products, including actions such as product cutting and slaughtering, cooking, and shaping. This stage involves all procedures in the area of quality management, the physical distribution of products, the processes at wholesalers and in supermarkets, and the sales process. In this definition, the last stage of the food value chain refers to consumption [4]. By comparison, Parfitt et al. (2010) choose a definition with a higher degree of detail, consisting of eleven steps. Similar to Gustavsson et al. (2011), this definition starts with agriculture, but here, it explicitly includes harvesting and the handling of raw materials during harvesting in the first step. As a second step, this approach describes threshing, which is equivalent to the second step of the previously described approach, post-harvest processing. This step is separated from the actual processing stage, as they are usually carried out either directly in the agricultural enterprises or in enterprises nearby. As a third step, this approach describes the drying in connection with the transport and distribution of raw materials, while the fourth step involves storage. This storage phase is followed by primary production in the fifth step, secondary production in the sixth, and quality control in the seventh. The eighth step involves packaging, including weighing, labelling, and sealing, while the ninth step focuses on marketing — generating publicity, selling, and distributing to the end customer. The consumer stage occurs in step ten before giving way to the 
eleventh step, the end of life, which is understood as the removal of waste at various stages of the value chain [10]. Figure 1 illustrates these two descriptions of the generic food value chain.

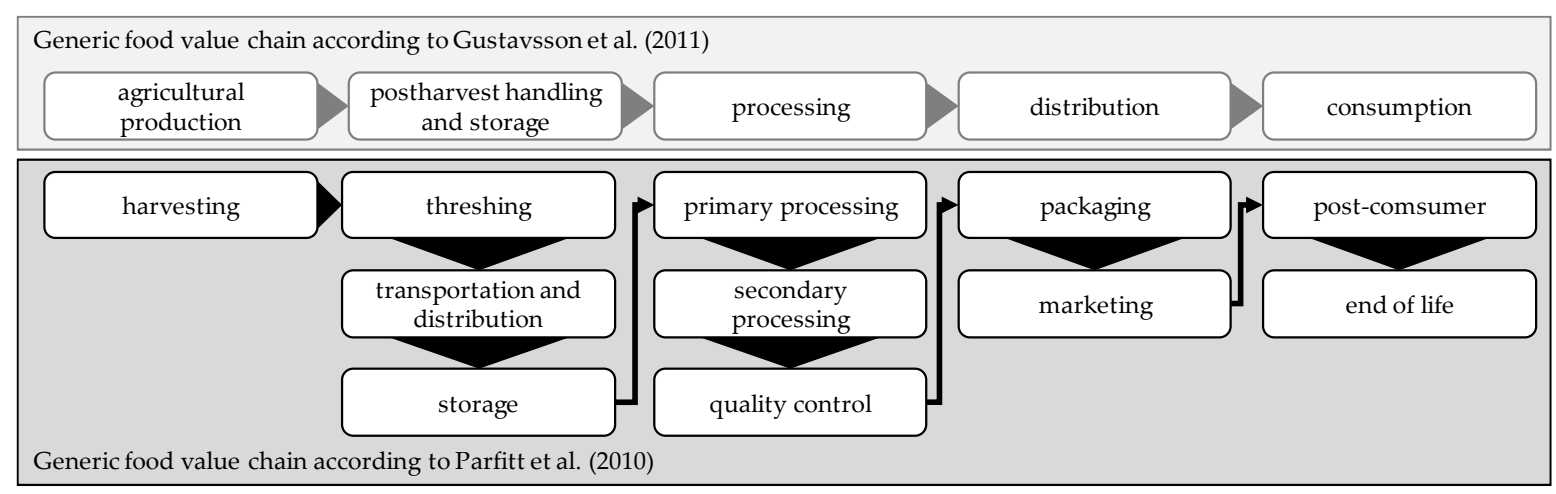

Figure 1. Generic food value chain $[4,10]$.

Both approaches outline the most important process steps of a generic food value chain, which relate to the actors directly involved. However, it should be noted that not all relevant actors are covered by the process steps. In comparison with other sectors, the food value chain is characterized by a high degree of influence from indirect actors. For example, Dani (2015) emphasizes the important position of regulatory authorities. Governmental regulation plays a particularly important role, as it sets out individual regulatory requirements for each country, for aspects like product quality. Governmental regulation is also important in international food value chains because different countries have varying requirements and guidelines with regard to market liberalization and protectionism against foreign imports [11]. Figure 2 provides a schematic illustration of the actors and functional areas in international value chains.

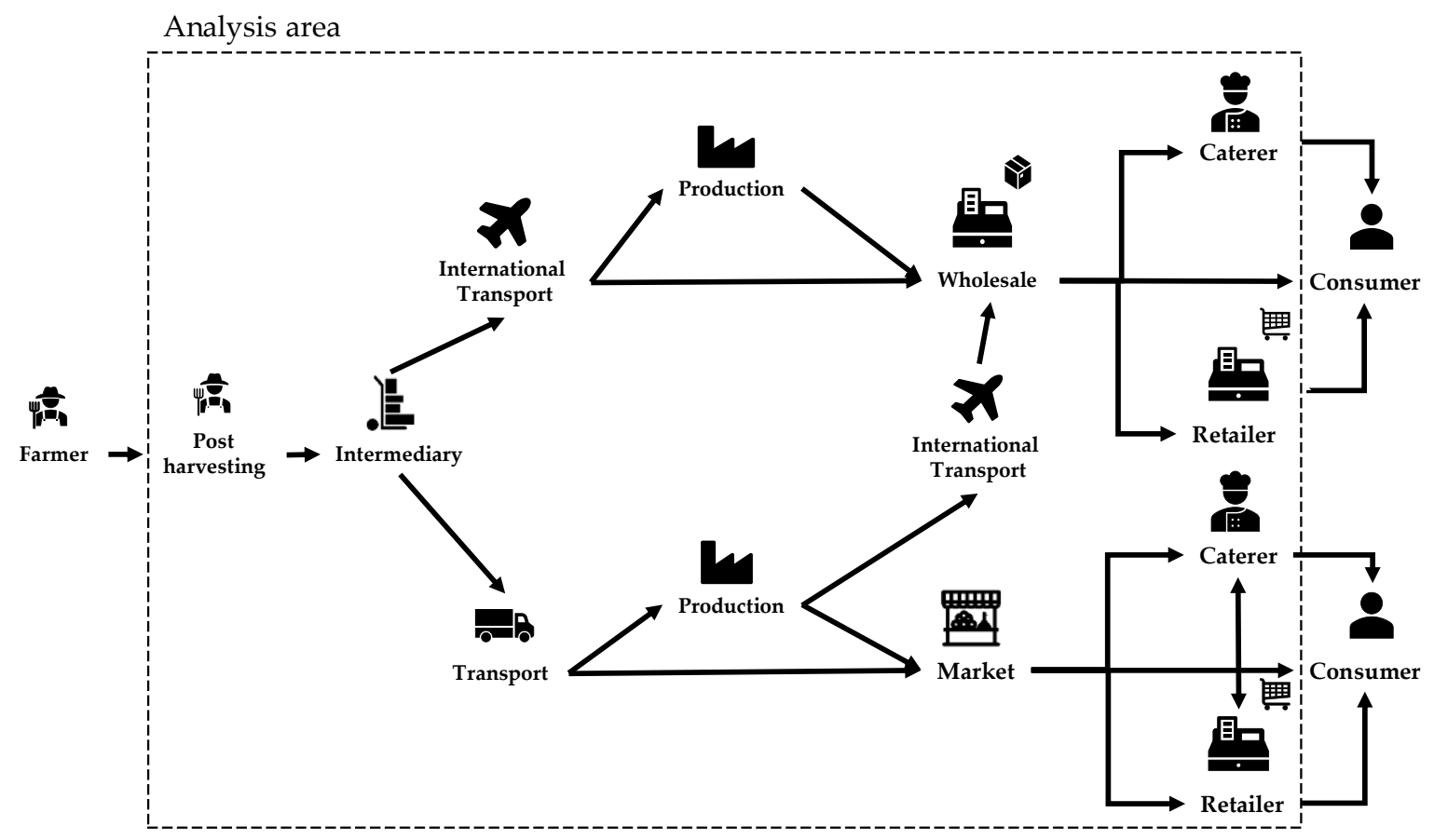

Figure 2. Functional areas and actors in international food value chains.

The current study investigates measures that can be implemented by direct and indirect actors within the food value chain using the logistics framework and definition described in this section. Following this understanding of logistics, the current study will consider the food value chain only in the 
context of an environment that is directly influenced by these actors. According to this understanding, the consumer level is not considered, as it lies outside the described actors' sphere of influence.

\subsection{Food Loss Management}

The literature also includes various descriptions of the terms "food loss" and "food waste". According to the definition by the FAO Report "The State of Food and Agriculture" (2019), food loss is "the decrease in the quantity or quality of food resulting from decisions and actions by food suppliers in the chain, excluding retail, food service providers and consumers" [12] (p. 5). Distinct from food loss, food waste is understood as "the decrease in the quantity or quality of food resulting from decisions and actions by retailers, food services and consumers" [12] (p. 5). Some authors make no distinction between these terms and combine them into "food loss and waste" [10,13]. The High Level Panel of Experts on Food Security and Nutrition of the European Union (HLPE) defines the terms as follows: "Food losses (FL) refers to a decrease, at all stages of the food chain prior to the consumer level, in mass, of food that was originally intended for human consumption, regardless of the cause." Meanwhile, "food waste (FW) refers to food appropriate for human consumption being discarded or left to spoil at consumer level-regardless of the cause." [14]. As the latter definition of food loss has the largest intersection with the scope of this study, the term "food loss" is used in accordance with the understanding of HLPE 2014.

The causes of food losses are complex and depend on conditions in the respective processes as well as the level of development in a given country. Parfitt et al. (2010) and Nitsche et al. (2018) describe the different causes of loss in developing and industrialized countries, an overview of which can be found in Table 1.

\subsection{Measures to Combat Food Losses}

In categorizing the many different approaches to dealing with food losses in the food value chain, Papargyropoulou et al. (2014) created the so-called food waste hierarchy, which is shown in Figure 3.

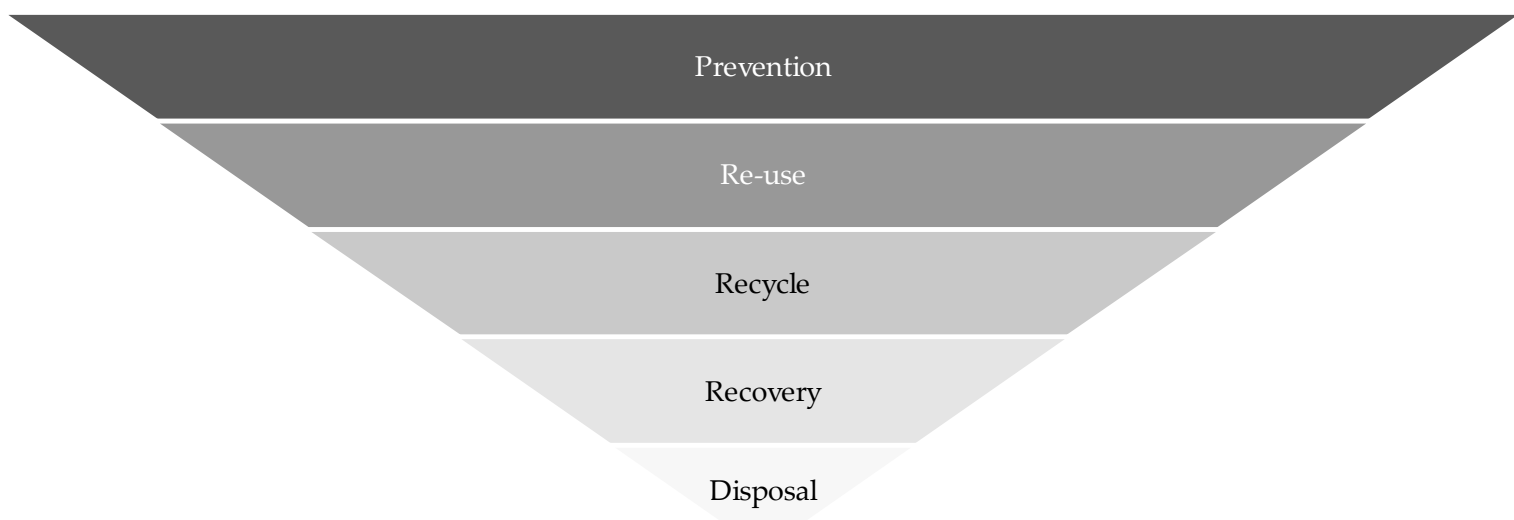

Figure 3. Food waste hierarchy [15].

In the first stage, prevention involves avoiding food surpluses or losses during production and consumption within the food value chain. Re-use refers to measures to pass on food surpluses to those in need, such as through redistribution networks. Recycling includes the subsequent use of surpluses for animal feed or composting. Recovery refers to the production of energy through these surpluses. The last level of the hierarchy is disposal, which describes the elimination of surpluses in a technical landfill. According to Papargyropoulou et al. (2014), the stages should be followed in the order described here, if measures are to be taken against food losses [15]. According to this definition, prevention is the most desirable form of action; as such, the following section of this study will consider measures that pursue this objective. 
Table 1. Causes of losses in food value chains $[7,10]$.

\begin{tabular}{|c|c|c|}
\hline Value Chain Stage & Developing Countries & Developed Countries \\
\hline $\begin{array}{l}\text { Harvesting and } \\
\text { post-harvesting }\end{array}$ & $\begin{array}{l}\text { weather-related loss } \\
\text { * } \quad \text { daboptimal harvest period } \\
\text { inadequate infrastructure } \\
\text { low level of automation } \\
\text { defective harvesting equipment } \\
\text { lack of qualified personnel }\end{array}$ & $\begin{array}{ll}* & \text { weather-related loss } \\
\text { over-production } \\
\text { damage of crops }\end{array}$ \\
\hline $\begin{array}{l}\text { Food processing } \\
\text { industry }\end{array}$ & $\begin{array}{l}\text { * transformational processes } \\
\text { contamination }\end{array}$ & $\begin{array}{ll}* & \text { transformational processes } \\
* & \text { production failures } \\
\text { * technical issues }\end{array}$ \\
\hline Warehousing & $\begin{array}{l}\text { low storage capacity } \\
\text { inappropriate storage conditions and } \\
\text { cooling systems } \\
\text { long distances to warehouses } \\
\text { warehouse usage not aligned to } \\
\text { customer demand }\end{array}$ & $\begin{array}{l}\text { technical malfunction of } \\
\text { cooling systems } \\
\text { manual errors in cooling regulation } \\
\text { inappropriate storage conditions }\end{array}$ \\
\hline Transportation & $\begin{array}{l}\text { * } \quad \begin{array}{l}\text { inadequate infrastructure } \\
\text { inappropriately equipped } \\
\text { transport vehicles }\end{array} \\
\text { low transportation safety for } \\
\text { perishable goods } \\
\text { * } \quad \text { unreliable transport packaging } \\
\text { inappropriate load securing }\end{array}$ & $\begin{array}{l}\text { long throughput times } \\
\text { long transport distances } \\
\text { delivery delays } \\
\text { overloading of terminals } \\
\text { inadequate temperature } \\
\text { measurements } \\
\text { unreliable transport packaging }\end{array}$ \\
\hline Retail & $\begin{array}{l}\text { - lack of cooling systems } \\
\text { inappropriately equipped storage and } \\
\text { sales areas } \\
\quad \text { unhygienic conditions }\end{array}$ & $\begin{array}{ll}* & \text { inaccurate sales forecasts } \\
\text { * incertainty regarding date indications } \\
\text { inappropriately equipped sales areas } \\
\text { inefficient optimization efforts } \\
\text { promotions and discounts }\end{array}$ \\
\hline Packaging & $\begin{array}{l}\text { - lack of packaging knowledge } \\
\text { inappropriate packaging for } \\
\text { transportation and storage }\end{array}$ & $\begin{array}{ll}* & \text { large packaging units } \\
\text { * } & \text { defective packaging } \\
\text { * inefficient packaging design }\end{array}$ \\
\hline Processes & $\begin{array}{l}\text { lack of holistic view of value adding } \\
\text { processes in food value chains due to } \\
\text { profit optimization }\end{array}$ & $\begin{array}{l}\text { high complexity of } \\
\text { value-adding processes } \\
\text { lack of holistic view of value-adding } \\
\text { processes in food value chains } \\
\text { lack of communication } \\
\text { lack of transparency along the food } \\
\text { value chain }\end{array}$ \\
\hline $\begin{array}{l}\text { Guidelines and } \\
\text { regulations }\end{array}$ & & $\begin{array}{l}\text { specification of aesthetic standards of } \\
\text { regulating authorities } \\
\text { high consumer requirements } \\
\text { guidelines for waste disposal due to } \\
\text { non-suitability for processing } \\
\text { seasonality or weather-related change } \\
\text { of quality/appearance specifications } \\
\text { by retailers } \\
\text { rules to ensure that there is a } \\
\text { minimum time left to the } \\
\text { expiration date }\end{array}$ \\
\hline
\end{tabular}


A great deal of research has focused on addressing loss prevention. For example, Nitsche et al. (2018) provide an overview of various measures, referring to a connection between the stages of the value chain and the measures implemented. This overview is shown in Figure 4.

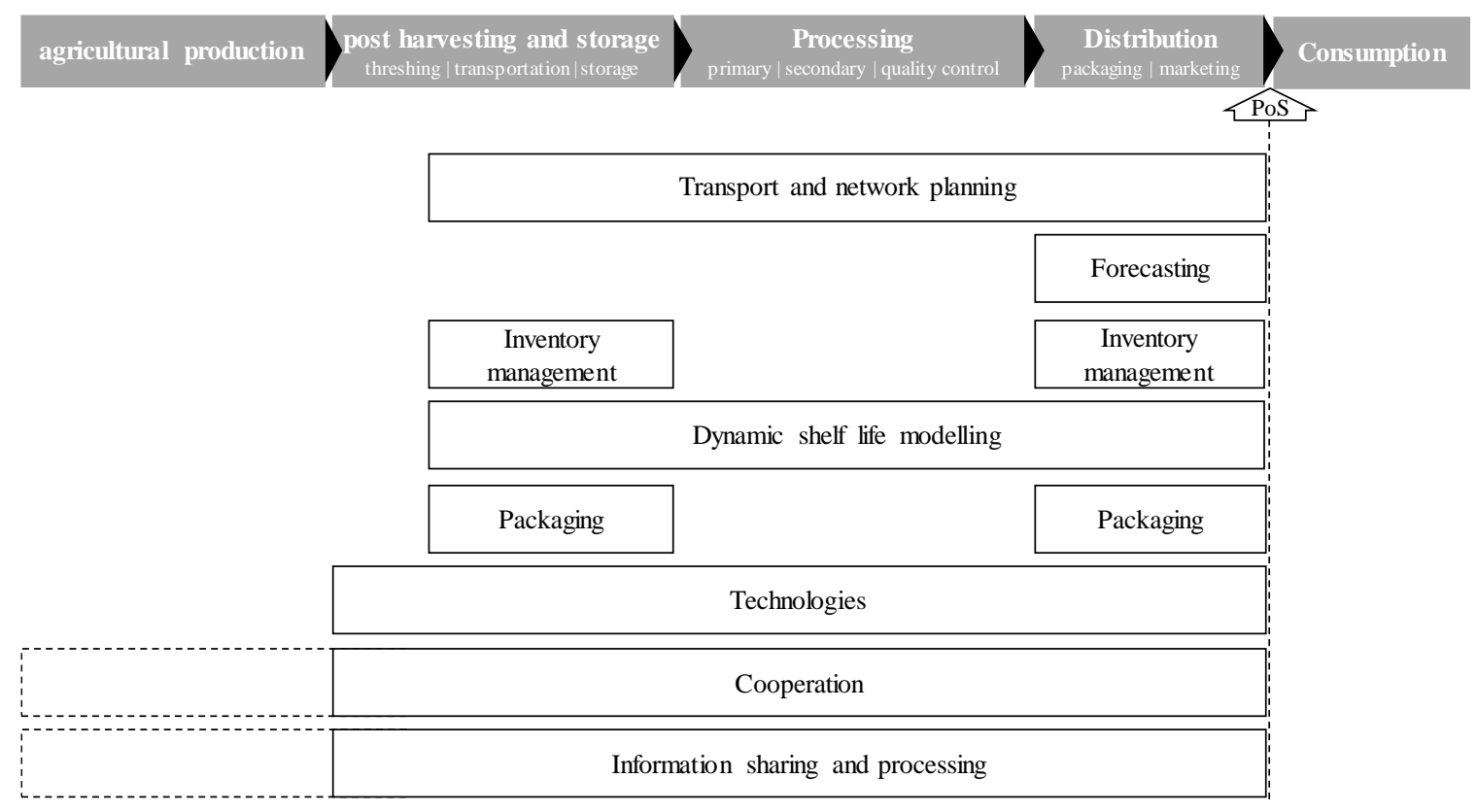

Figure 4. Assignment of measurement clusters to the stages of a food value chain [7].

This overview shows that there are measures in many different areas of the value chain. However, this view refers exclusively to the measures implemented and does not provide any decision support for users seeking to develop a suitable measure for a specific application. What is missing for this purpose is a set of fields of action oriented towards specific objectives. Such a set of fields would make it possible to develop practical and customized solutions for individual cases.

\section{Materials and Methods}

The research methodology follows Nitsche and Durach's (2018) research, pursuing a dual approach that incorporates both the perspective of science and the perspective of logistics practice [16]. Firstly, this study incorporates open interviews in order to integrate the practical side. Secondly, a systematic literature analysis assists in mapping the research question. By triangulating the data from both sources, comprehensive statements can be made.

Six open interviews were conducted with practitioners from companies and organizations operating within the range of the above-mentioned value chain structure. The interviews opened with the following question: which measures against food losses have you already implemented or noticed in the environment? Subsequently, the interviewers inquired more deeply into the objectives behind the described measures before discussing the areas in which improvements could be achieved. Based on these interviews, different criteria were extracted and used to design measures against food losses according to the experts' statements. From the six interviews, a total of 24 criteria were gathered.

The second part of the data collection is based on a systematic literature analysis by Durach (2016) [17], who describes systematic literature analysis as a process with six phases. Starting from a clear objective formulated in a research question, the need for research should be ensured by involving relevant stakeholders. Moreover, the researcher should reflect on the question of whether or not the question can be answered by reviewing the literature. The second step involves preparing the literature analysis by setting inclusion and exclusion criteria. In the third step, the literature search is carried out after choosing a methodology (e.g., database analysis, snowball sampling). Then, the analysis 
is performed by creating a search string and entering it into the selected databases. The fourth step involves applying the previously-defined inclusion and exclusion criteria and assessing the quality or validity of the literature. The fifth step is the analysis and synthesis of the literature under investigation. Here, Durach (2016) does not specify an evaluation method. However, he describes the importance of an objective and transparent approach and recommends involving several researchers in this step in order to minimize bias. The sixth step includes the dissemination of the results and the use of the research findings [17].

The systematic literature analysis only included scientific journals. Renowned researchers in the field assisted in creating the search string. For this purpose, authors who were identified by previous basic analysis of the literature were contacted who had been active authors who had published on similar topics and whose contact details were openly accessible online. They were informed about the primary research question and asked to name terms that they would use for such a search. Out of 30 scientists contacted, eight responded. The search terms mentioned were compared with the previously identified terms, which were supplemented if necessary. This process served to minimize the influence of one person (researcher bias) and to develop a more comprehensive search string.

The search logic resulting from this process is shown in Figure 5.

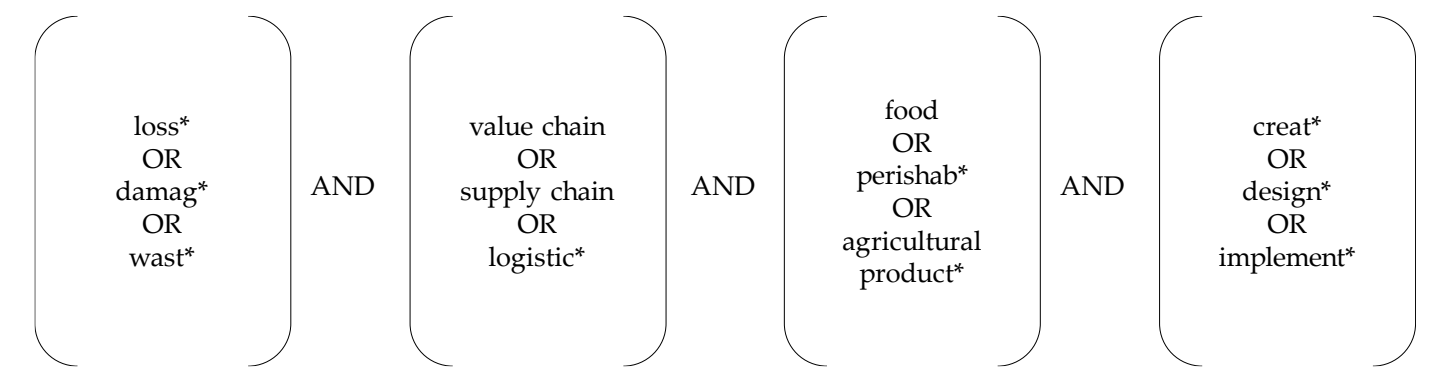

Figure 5. Logic of the search string. * To make the search string non-repeating, some words have been marked with asterisks to include different word endings in the search.

The following inclusion and exclusion criteria were then defined:

Inclusion criteria:

- Only peer reviewed journals are used.

- Only journal articles written in English are used.

- Only articles that were available in the EBSCO Host and Web of Science databases at the time of the search (March-May 2019) are used. There was no limitation in terms of the year of publication.

- Only articles showing a focus on the design of food logistics network in the title or abstract are used.

\section{Exclusion criteria:}

- Articles focusing on biological, chemical, or medical criteria will not be considered.

- Articles focusing on waste reduction at the level of the final consumer will not be considered.

The same terms were used for the search in the mentioned databases. Due to differing search logics, search strings were structured in varying ways. The search resulted in a total of 887 results in both databases. After correcting for duplicates (89) and deleting articles that did not meet the inclusion criteria (20 book contributions, one conference volume, and 18 anthologies), 759 articles remained for closer examination (reading the title and abstract). During this process, 649 articles failed to meet the inclusion criteria. Figure 6 provides an overview of the distribution of the analyzed articles' publication years. 


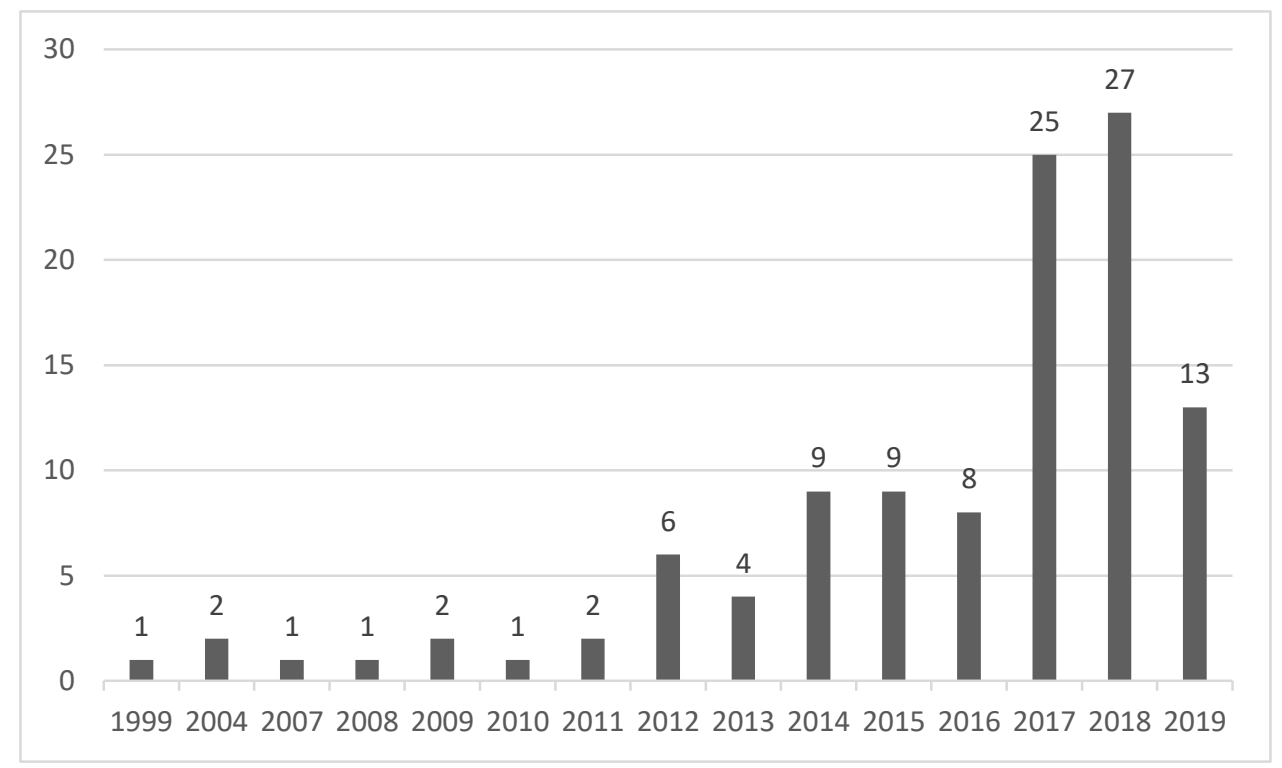

Figure 6. Distribution of publication years of included articles.

Among the 111 articles examined, 18 explicitly focused on value chains in developing countries. Seventeen articles explicitly addressed value chains in industrialized countries, while the remaining 76 articles made no statement about an area of focus, or they referred to both developing and industrialized countries.

The remaining 111 articles were read, and the criteria mentioned in the articles collected. In each case, the criteria described in the article or interview were noted. A total of 646 criteria were identified using the two data collection methods. The collection of criteria is illustrated in Figure 7.

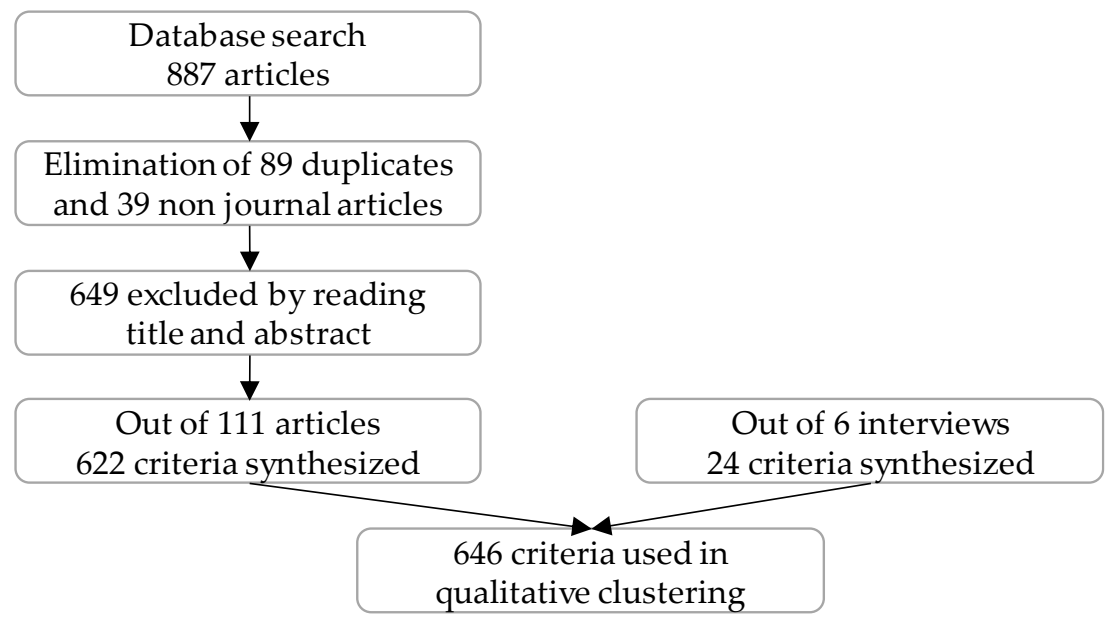

Figure 7. Selection process.

Using qualitative clustering, three researchers systematized the criteria identified in the study. The located criteria were presented to the three participants. In each case, they discussed whether the criterion fit a previously-found criterion or whether it encompassed a new group. This approach gradually led to the creation of fields of action, which were then structured more specifically and combined to form a complete overview. 


\section{Results}

The identified fields of action can be classified into four main groups. The first group refers to fields of action that aim to "optimize processes". The second group combines fields of action that relate to the "framework conditions" of the logistics network and are primarily addressed by the public sector. The third group refers to the "physical characteristics" of the respective food products handled. In this respect, major differences can be seen regarding the products under consideration. The fourth group includes the fields of action focused on "people" within the logistics network. Figure 8 shows the breakdown of the identified fields of action for the groups mentioned.

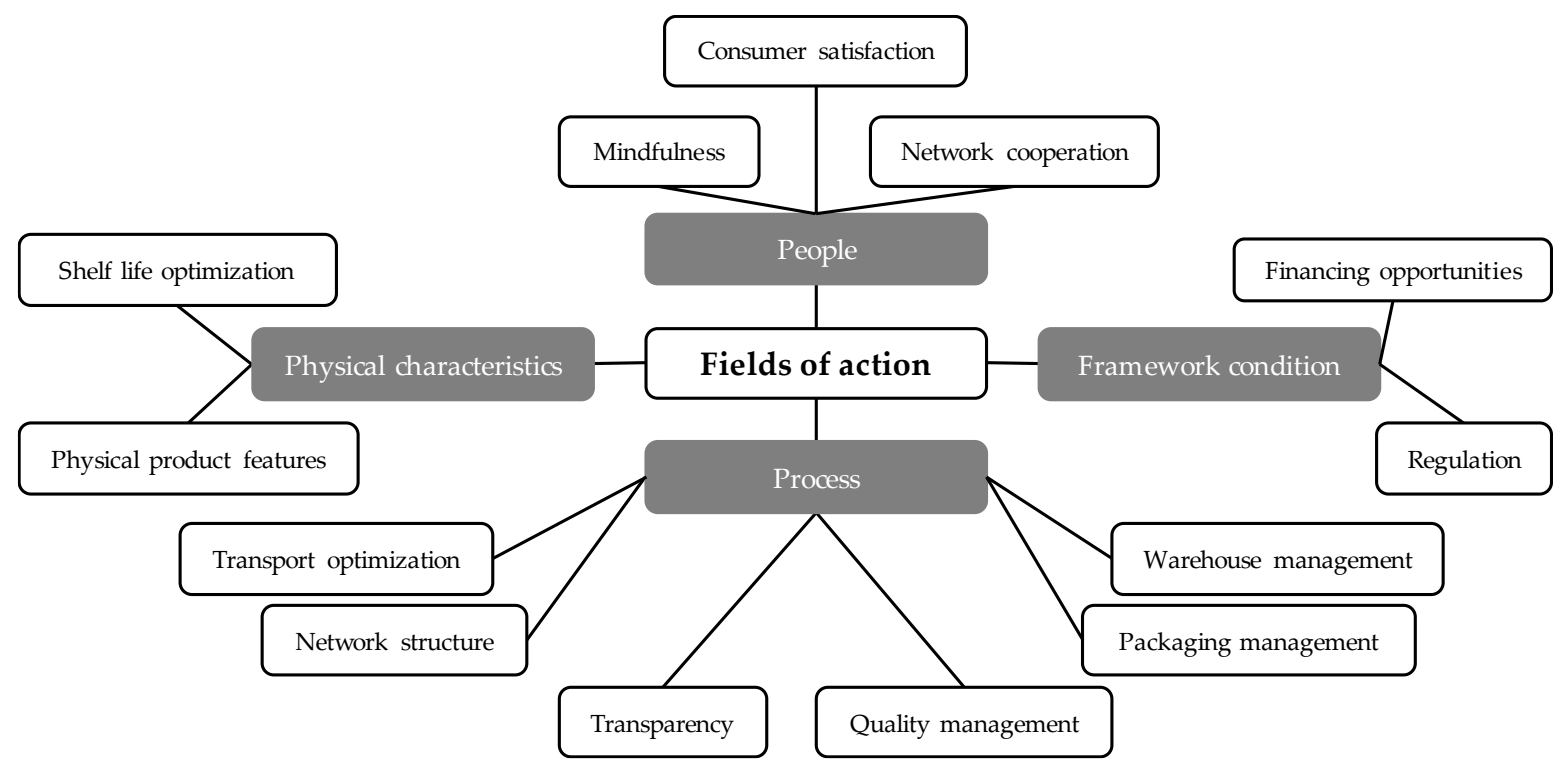

Figure 8. Classification of fields of action.

Table 2 shows the mapping of the articles found in the systematic literature analysis to the identified fields of action.

\subsection{Optimizing Processes}

Six fields of action were identified in the process optimization group, with transparency being the most frequently mentioned within this group. Indeed, 29 articles and three expert interviews addressed this issue. In this context, transparency is understood as the creation of a uniform information base within a company or across a logistics network. By reducing information asymmetry, decisions are better coordinated, and network partners have the opportunity to react better to their partners' actions. Nearly all of the articles mentioned the use of technology for realizing transparency. However, some researchers also explained more profound interrelationships and described the added value of transparency for the networks [18,19]. Sarpong (2014), for example, examined the influence of the horse meat scandal on the European market and its effects on discussions of transparency [20]. In terms of technology use, researchers discussed a variety of procedures, including the use of real-time monitoring for cross-company processes [21]. Other articles discussed the introduction of the Internet of Things and analysis methods based on it [22,23]. According to this analysis, the introduction of tracking and tracing technologies is an important step towards a uniform information base across a network [20,21,23-25]. Also of high importance in the field of action for transparency is the use of decision-making tools that provide the decision maker with information permitting a more transparent decision-making process [26,27]. Another group of articles discussed the introduction of lean philosophy, which should lead to a more efficient process while encouraging a higher level of process understanding and create additional knowledge and transparency [28-30]. 
Table 2. Mapping the literature to the criteria.

\begin{tabular}{|c|c|c|}
\hline Fields of Action & Description & Literature \\
\hline Transparency & $\begin{array}{l}\text { Increase of transparency within a } \\
\text { company as well as between companies } \\
\text { of a network }\end{array}$ & $\begin{array}{l}\text { Addisu Damtie 2015; Antman et al. 2014; Borit and } \\
\text { Santos 2015; Brewster et al. 2017; Chaudhuri et al. } \\
\text { 2018; Chimphango and Görgens 2015; Chuang et al. } \\
\text { 2017; Colgan et al. 2013; Faour-Klingbeil et al. 2016; } \\
\text { Herbon and Khmelnitsky 2017; Irani and Sharif 2016; } \\
\text { Kaipia et al. 2013; Kamble et al. 2019; Manzouri et al. } \\
\text { 2014; Martens et al. 2012; Melin and Barth 2018; } \\
\text { Mercier et al. 2018; Muriana 2017; Nabhani and } \\
\text { Shokri 2009; Notarnicola et al. 2017; Pinior et al. 2015; } \\
\text { Powell et al. 2017; Sarpong 2014; Shah and Naghi } \\
\text { Ganji 2017; Strotmann et al. 2017; Sharifzadeh et al. } \\
\text { 2015; Vlachos 2015; Wang et al. 2012; Xiao et al. } 2017\end{array}$ \\
\hline Quality management & $\begin{array}{l}\text { Improvement of quality management } \\
\text { for early detection of weaknesses }\end{array}$ & $\begin{array}{l}\text { Azuara et al. 2012; Chelbi et al. 2008; Lau et al. 2018; } \\
\text { Laux et al. 2015; Mor et al. 2018; Negi and Anand } \\
\text { 2019; Tsang et al. 2018; Wilcock and Boys } 2017\end{array}$ \\
\hline $\begin{array}{l}\text { Packaging } \\
\text { management }\end{array}$ & $\begin{array}{l}\text { Improvement of packaging } \\
\text { management during transport and } \\
\text { storage processes as well as for } \\
\text { distribution to the end customer }\end{array}$ & $\begin{array}{c}\text { Akkas et al. 2018; Mack et al. 2014; } \\
\text { Molina-Besch et al. 2019; Vanderroost et al. 2017; } \\
\text { Verghese et al. 2015; Wikström et al. 2019; } \\
\text { Wikström et al. } 2014\end{array}$ \\
\hline Transport optimization & $\begin{array}{l}\text { Improvement of transport management } \\
\text { with regard to route planning, loading } \\
\text { of vehicles, and coordination of vehicles }\end{array}$ & $\begin{array}{l}\text { Ahumada and Villalobos 2011; Bortolini et al. 2016; } \\
\text { Caixeta-Filho 1999; Hu et al. 2017; Memon et al. 2017; } \\
\text { Mvumi et al. 2016; Validi et al. } 2014\end{array}$ \\
\hline $\begin{array}{l}\text { Warehouse } \\
\text { management }\end{array}$ & $\begin{array}{l}\text { Improvement of warehouse } \\
\text { management using suitable storage } \\
\text { equipment, storage strategies, and } \\
\text { adapted layout planning }\end{array}$ & $\begin{array}{c}\text { Facchini et al. 2018; Garbaba et al. 2018; Haijema and } \\
\text { Minner 2016; Kiil et al. 2018a; Kiil et al. 2018b; } \\
\text { Leśniewski and Bartoszewicz } 2013\end{array}$ \\
\hline Network structure & $\begin{array}{c}\text { Improvement of the network structure } \\
\text { using strategic network planning and } \\
\text { location management }\end{array}$ & $\begin{array}{l}\text { Atkins et al. 2018; Gong et al. 2007; Orjuela Castro } \\
\text { and Adarme Jaimes } 2017\end{array}$ \\
\hline Regulation & $\begin{array}{l}\text { Adapted regulations by the } \\
\text { administration to support companies in } \\
\text { reducing food losses as required }\end{array}$ & $\begin{array}{l}\text { A. Rijpkema et al. 2014; Brunelle et al. 2017; } \\
\text { Cristóbal et al. 2018; Mendedo et al. 2017; } \\
\text { Pinstrup-Andersen 2014; Sharma et al. 2019; } \\
\text { van Hoof and Lyon } 2013\end{array}$ \\
\hline $\begin{array}{c}\text { Financing } \\
\text { opportunities }\end{array}$ & $\begin{array}{l}\text { Providing appropriate financial support } \\
\text { from the administration to weaker } \\
\text { network partners }\end{array}$ & Brüntrup et al. 2018; Wu et al. 2017 \\
\hline Physical characteristics & $\begin{array}{l}\text { Adaptation of processes to consider } \\
\text { special physical requirements of the } \\
\text { products, including temperature, } \\
\text { pressure sensitivity, and air composition }\end{array}$ & $\begin{array}{l}\text { Bakhtavar et al. 2019; Hafliðason et al. 2012; } \\
\text { La Scalia et al. 2016; Martindale and Schiebel 2017; } \\
\text { Raab et al. 2011; Raut and Gardas 2018; } \\
\text { Singh et al. } 2018\end{array}$ \\
\hline Shelf-life optimization & $\begin{array}{l}\text { Process adaptations that allow the shelf } \\
\text { life of the products to be taken into } \\
\text { account in decision making }\end{array}$ & $\begin{array}{l}\text { Chen et al. 2018; Allen and Schuster 2004; Gogo et al. } \\
\text { 2017; Kaya and Ghahroodi 2018; Tromp et al. 2012; } \\
\text { Venuto and Mezzina } 2018\end{array}$ \\
\hline Network cooperation & $\begin{array}{l}\text { Improving cooperation within networks, } \\
\text { including information sharing and } \\
\text { efforts to develop comprehensive } \\
\text { measures against food losses }\end{array}$ & $\begin{array}{l}\text { Aggarwal and Srivastava 2016; Alarcon et al. 2017; } \\
\text { Alberti and Belfanti 2019; Arias Bustos and Moors } \\
\text { 2018; Borrello et al. 2017; Despoudi et al. 2018; } \\
\text { Devin and Richards 2018; Fang Du et al. 2009; Fu et al. } \\
\text { 2018; Henningsson et al. 2004; Kouwenhoven et al. } \\
\text { 2012; Liljestrand 2017; Lozano and Adenso-Díaz 2018; } \\
\text { Lutz et al. 2017; Markelova and Mwangi 2010; } \\
\text { Mena et al. 2014; Ocicka and Raźniewska 2018; } \\
\text { Song and He 2019; Tsuchiya et al. 2015; } \\
\text { Warshawsky 2016; Yu et al. 2018; Zhou et al. } 2019\end{array}$ \\
\hline Mindfulness & $\begin{array}{l}\text { Promoting awareness among employees } \\
\text { at all levels in companies of the } \\
\text { relevance of the problem of food losses } \\
\text { in everyday life }\end{array}$ & $\begin{array}{c}\text { Alamar et al. 2018; Al-Madbouh et al. 2019; } \\
\text { Bonadonna et al. 2019; Martindale 2017; } \\
\text { Weidner et al. } 2019\end{array}$ \\
\hline Consumer satisfaction & $\begin{array}{c}\text { Adaptation of internal processes with } \\
\text { the aim of meeting specific customer } \\
\text { requirements }\end{array}$ & Aschemann-Witzel et al. 2017; Pan et al. 2017 \\
\hline
\end{tabular}


The second most frequently mentioned field of action is the improvement of quality management. Eight of the articles identified in the current research deal with this topic. This field of action involves seeking to detect errors in the process as early as possible in order to mitigate them. Researchers that used measures in pursuit of this objective also tended to use technology, which was also mentioned in terms of transparency. For example, Azuara et al. (2012) discussed introducing effective tools that make it possible to detect faulty or counterfeit products in incoming goods, thus facilitating the handling of such products before they are introduced into the production processes [28,31]. Studies have also mentioned process structuring and adapting current quality regulations [32,33]. Similar technologies to those already mentioned in creating transparency also contribute to increasing and improving quality management. Thus, several authors pointed to certain technologies that aim to improve quality management. For example, tracking and tracing leads to improved quality management [34-36]. Studies also highlight the monitoring of temperature in cold chains as an effective tool for quality control [37,38].

Another field of action assigned for process optimization is packaging management. Here, packaging management is understood as the effort to pack goods appropriately for process steps during transport, handling, and storage. It also means designing packaging in such a way that it leads to the smallest possible amount of waste at the end-customer level. Seven articles and one interview addressed this topic. Within this area, many articles did not mention the reduction of food losses as the primary goal of the presented measures, a finding that is in contrast with most other articles examined in this analysis. Packaging management also was mentioned in the context of reducing packaging material usage, using sustainable packaging materials, and lowering process costs [39]. Many articles focused on designing the packaging in such a way that the final product creates as little waste as possible. In this sense, the topic of packaging size came up in several articles [40,41]; meanwhile, the topics of separation within packaging and the labelling of packaging also appeared [42].

Another identified field of action is transport optimization, which involves the optimization of operative transport processes as well as route planning. Seven articles discuss this topic. Articles assigned to this field of action dealt mainly with the development of mathematical models for route optimization [43-45]. In addition, the authors discussed the need for reliable transport processes to ensure that food is not wasted by delayed transport or inadequate load securing [46].

Warehouse management was identified as a further field of action. In this context, warehouse management is understood as the use of effective methods for optimizing warehouse management and for adjusting warehouse layout to meet requirements. A total of six articles fit into this category. The identified articles primarily focused on implementing reasonable warehouse strategies, such as the "first expired first out" principle [47]. Other authors concentrated on warehousing and the specific requirements of the early stages of the logistics network, more specifically, on the level of farmers. These studies focused on farming structures in developing countries and the specifics of the adaptation necessary for effective warehousing in these areas [48]. A few authors also discussed the optimal warehouse layout for shortening distances and keeping the duration of products' stay within warehouses as short as possible [49].

The optimization of the network structure also was identified as a field of action. Here, adaptation of the network structure refers to the objective of building an efficient distribution network. Increasing the efficiency of these measures reduces food loss. Three articles fell into this field of action. In this context, it should be noted that reducing food loss is only a sub-target. Thus, this field of action differs from most of the other fields of action, which were identified as clear main goals in terms of reducing food loss. These articles primarily focused on strategic planning approaches to optimizing network design and developing an optimized distribution network [50,51].

\subsection{Framework Conditions}

Within the framework conditions group, regulation was the most frequently mentioned field of action. Under this field of action, seven articles and two interviews were categorized. Regulation in 
this context means the intervention of governmental authorities on the processes within food logistics networks. Through the identified articles, it became clear that regulatory measures must be implemented cautiously; otherwise, they will lead to additional losses within the logistics networks $[52,53]$. This field of action usually is not set by the companies themselves; rather, it involves an external field of action that companies can influence through participation in initiatives, for example [54].

The second field of action mentioned under framework conditions is financing opportunities. Here, financing opportunities refer to network partners receiving financial support either from other companies within the logistics network, or in most cases, from governmental or non-governmental organizations. This field of action was addressed in two articles, both of which explicitly refer to developing countries. The articles both contain detailed discussion of the fact that losses can be reduced by using targeted financial support, especially for network partners at the beginning of the value chain. This point is supported by the fact that, especially in developing countries, farmers with poor equipment depend heavily on their partners within the value chain. Therefore, they have little financial flexibility or chance at process innovations; as such, they do not focus on loss reduction $[55,56]$.

\subsection{Physical Characteristics}

Among the physical characteristics group, the most frequently mentioned field of action involved physical product features, with seven articles assigned to this field of action. In this context, considering physical product features means conducting process optimization with the aim of aligning the food's physical environment to its requirements. Here, temperature, air composition, humidity, and pressure sensitivity are all considered. Optimally adapting the physical environment to the product features extends the shelf life of the food. These articles most frequently mentioned optimization in terms of temperature. For example, they mentioned various technologies that enable optimal cooling within containers or even within department stores $[57,58]$. Other articles discussed the design of intelligent packaging, which can release additional gases to the surroundings according to the needs of the packaged food; such technologies also can influence air humidity [59,60].

The further field of action within this category is the optimization of shelf life, with six articles assigned to this field of action. In this context, shelf-life optimization is understood as measures that specifically extend the shelf life of the products through various process optimizations or process changes. As an example, we can consider the dynamic calculation of product life combined with storage strategies in order to allow food to be controlled more effectively throughout the entire process [61]. Another goal mentioned in the articles was dynamic pricing depending on the remaining shelf life of the products. In these articles, the remaining shelf life of the products also was recalculated by dynamic calculation based on the current conditions; then, earlier expiring articles were priced lower and put on sale [62].

\subsection{People}

The second most frequently mentioned field of action overall was an increase in network cooperation. In this context, increasing network cooperation reflects the efforts of various network partners to establish optimal cooperative relationships with suppliers, customers, and other network partners. A total of 22 articles and three interviews were assigned to this aspect. Many of these articles assert the view that improved cooperation between the partners not only increases transparency but also, and above all, strengthens the bond between the partners. Meanwhile, it also increases the partners' desire to contribute to process optimization. Alternatively, this improved cooperation may provide partners with the opportunity and security to carry out this optimization themselves [63-65]. Such optimization may be done for financial and strategic reasons within the cooperation. A social component also plays a role in very close business relationships [66]. Three articles within this classification explicitly address cooperation in developing countries while focusing on small farmers and small markets. They show that, especially in this context, a strong relationship can improve the 
position of the weaker network partners and, thus, strengthen their ability to tackle process efficiency and loss reduction [67-69].

Mindfulness is a further field of action assigned to the group of people. Mindfulness in this context refers to efforts to sensitize all network partners, the company workers, and the end customer to the special features of food while increasing awareness about product wastage. Five articles were assigned to this field of action. The examined articles showed that increased awareness among management, employees, and end consumers leads to an understanding that waste can be reduced by more careful product handling $[65,70]$. Furthermore, this increased awareness promotes employee commitment to approach the problem and to make creative suggestions for improving the situation $[65,71]$.

The third field of action within this group is consumer satisfaction. In this context, consumer satisfaction is understood to include efforts that are primarily designed to meet specific customer requirements, thus reducing waste at the customer level. Two articles were assigned to this field of action. One study mentioned that specific offers, such as home delivery or sales offers (e.g., cook boxes), fulfilled certain customer needs, and through this orientation the customer tends to waste less [65,72].

\section{Discussion}

The fields of action presented hold varying relevance for different actors within the food value chain. Considering framework conditions is particularly relevant for actors at the regulatory level. For example, the adaptation of regulations, as they apply in the European Union for certain products, should always consider the effects on losses. Similarly, subsidies and other financial support for companies should be adjusted in terms of their effects on losses. Weaker actors should be supported, especially in developing countries. As shown, these tools can be used to empower small- and medium-sized enterprises in particular, making them more effective in their process execution while achieving lower loss rates. The fields of action of the other groups are mainly relevant for active players in the food value chain. Here, however, the relevance depends partly on the position within the value chain. When it comes to developing future measures, producers and logistics service providers especially should consider the fields of action of the process group for themselves. The group of physical characteristics concerns all active actors in the value chain, as improving both shelf life and the product environment can bring added value by taking into account the product's physical properties at all points in the value chain. The people-related fields of action have to be considered separately. Mindfulness is to be considered at all points of the value chain, as increased care of the products under consideration can reduce losses. Customer satisfaction, on the other hand, becomes especially relevant for the actors at the end of the value chain as they are in direct interaction with the customers. Network cooperation, as a field of action, is also relevant for all active actors within the value chain and should be given high priority in the planning and design of measures against food losses.

The results presented summarize the current state of the scientific research in the field of food loss reduction and provide added value for science and industry in this area. For those seeking to develop measures to reduce food losses, the presented systematization offers practitioners an overview of the objectives with which successful measures against food losses can be generated. Many of the presented fields of action refer to internal company processes. Concentrating on these fields of action will increase resource efficiency within the company and, therefore, also assist in reducing food losses within the entire network. However, there is also the risk of losses being shifted to the previous network partners due to improvements in the later stages of the value chain. This effect is particularly problematic in the context of internationally networked value chains originating in developing countries. Due to the unequal balance of power between the partners involved, the weaker partners in developing countries often bear an additional burden. The analysis presented has shown that many authors agree that an effective reduction of food losses within the entire network can be achieved primarily by creating transparency and improving cooperation within the network. This approach does not simply shift losses, but rather minimizes weak points while reducing losses through increased cooperation. 
Because increased cooperation at eye level strengthens the weaker partners in the network and can make them economically more successful in the long term, this approach can also ensure supply security within the network. This approach not only reduces losses but also strengthens the network in the long term.

Overall, the fields of action are not necessarily selective; there may be overlaps of measures across several fields of action. For example, measures that are introduced in the early phase of the value chain, e.g., through more effective transport management, also influence later warehouse processes most of the time. Packaging management is also closely linked to transport optimization. Meanwhile, correct loading ensures adequate packaging of food during transport. As already mentioned, the use of various technologies is also possible in many individual fields of action. This area includes tracking and tracing, as well as the general use of IT and related data analytics methods. These technologies almost always create an improved general information base. Combining technology with an openness to share this information with value-added partners in the network relates to the transparency field of action. In general, it can be said that increased transparency in almost all fields of action will have positive effects. As such, it can be concluded that increased transparency has the greatest added value within a holistic approach to reducing food losses in value chains.

Developing countries face a hunger problem and a difficult supply situation, requiring close attention when categorizing into fields of action. One way to strengthen the local economy and thus improve the availability of financial resources for food procurement would be to increase the participation of actors in developing countries in international value chains. Despite other problems, such as general trade restrictions and inadequate trade routes, improvements can be achieved by taking the fields of action described here into account. At the same time, overall productivity and the availability of food for the local market can be increased by avoiding food losses. Support at the administrative level is particularly effective for small farmers and small enterprises. In this case, however, it must be remembered that these measures should be used with caution, i.e., exclusive financing of measures. Without effective long-term implementation, training and knowledge transfer to the small entrepreneurs concerned cannot be sustainable. In addition, the issue of quality management is particularly relevant for actors in developing countries who aim to participate in international value chains. In many cases, the problem is that quality standards cannot be achieved, and thus, unnecessary losses occur on the export route. In this sense, quality management takes on critical importance in developing countries. Furthermore, it should be noted that transport optimization is also a major challenge in developing countries due to a lack of transport means and suitable containers. As a result of incorrect transport loading, many products are lost, especially in the early stages of the value chain. To implement this area of improvement, it is essential not only to have the technical equipment but also the personnel capability in ensuring adequate food handling. In this case, the focus on the criteria is particularly strong. Employees require training to bring them closer to the specifics of traded food, a target-oriented measure. The use of sensible technologies also holds considerable potential for developing countries.

The analysis of the derived fields of action shows that the fields of action differ not only in terms of their sphere of action, but also in terms of their extension across actors and in terms of the management levels applied. Therefore, the individual fields of action can be classified into schema between strategic and operative application. They may also be distinguished by their separation between internal company application and cross-company application. As a result, the fields of action in the framework conditions group can be defined as strategic fields of action. Financial opportunities are usually given at the individual company level. Regulatory requirements typically apply to or involve overarching processes and are therefore more likely to be classified at the cross-company level. The fields of action of the people group, however, are to be assessed differently. Consumer satisfaction involves a field of action that is applied within a company and can include both strategic and operational measures. Network Cooperation always contains cross-company measures and therefore can be assigned at the cross-company level. Within this field of action, however, both strategic and operative measures are combined. The mindfulness field of action is to be placed on the operative level, because here, above all, 
training and other operative awareness-creating measures are included. Mindfulness can be achieved both within a company and through cross-company measures. Among the physical criteria group, neither physical product features nor shelf-life optimization are applied internally or across companies exclusively. Both can be addressed on both levels by suitable measures. Measures in the field of shelf-life optimization are primarily operational, in that they are mainly organizational measures. The field of action involving physical product features, on the other hand, can be implemented both through operational and through strategic measures, and it is thus positioned between the two.

With regards to the process-oriented fields of action group, the results also reflect a heterogeneous situation. Network structure is a strategic field of action, which is addressed both within a company and through cross-company measures. Warehouse management is to be classified on the internal company level and includes both operative measures and strategic measures, such as layout planning. In most cases, quality management is an internal field of action, but there are also cross-company measures. Quality management is also classified at both the operational and strategic levels. Packaging management is an internal company function that functions almost exclusively at the operational level. According to the analyses, transport management is also represented both on the internal company level as well as on the cross-company level. Most of the measures mentioned for this field of action can be classified at the operational level, but there are also some strategic measures proposed within this field of action. Finally, the transparency field of action is to be mentioned. As already mentioned, transparency at all levels should be addressed in a meaningful way. Here, it should be noted that a holistic creation of transparency can only be fully achieved through the interaction of internal and cross-company measures. The situation is similar at the application level. Both operational measures, e.g., by using suitable technologies, and strategic measures are necessary. Figure 9 illustrates the classification described here.

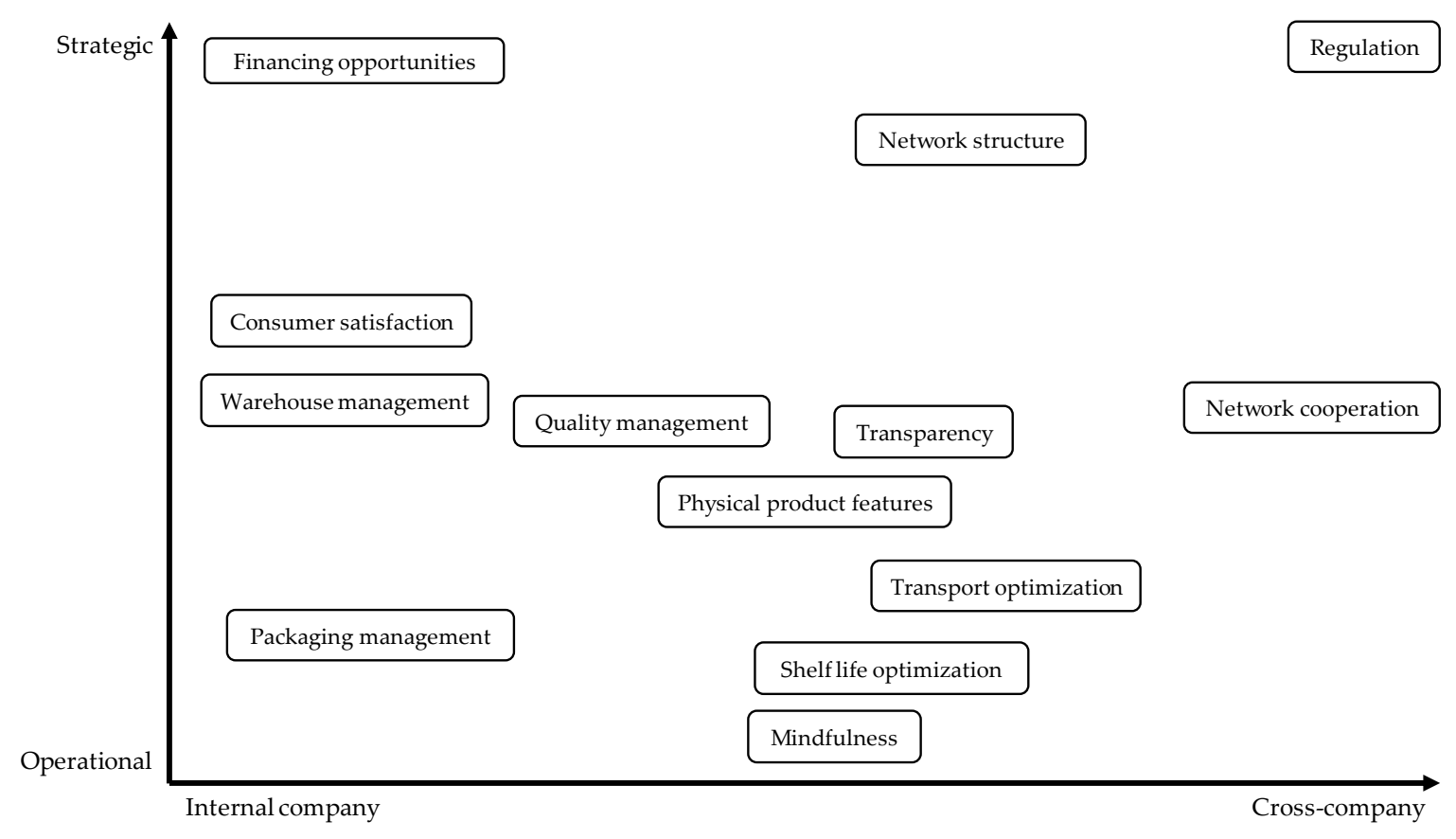

Figure 9. Classification of the fields of action according to application and company level.

\section{Conclusions}

This study aimed to answer the following research question: Which fields of action are set as objective parameters when developing logistical measures against food losses?

In order to answer this question, this paper first described a basic understanding of logistics. Furthermore, the context was set through a description of the food value chain according to current 
scientific understanding. By examining 111 articles compiled from a systematic literature analysis and six open interviews with practitioners, criteria were extracted as objectives for the development of measures against food losses. This process resulted in a framework including 13 fields of action in total, all of which could be assigned to four main groups: optimizing processes, framework conditions, physical characteristics, and people. The research question was answered by the framework presented. The analysis demonstrated that a uniform information basis in all fields of action would bring about improvements by optimizing processes, particularly because time is an essential parameter in avoiding food losses.

\subsection{Scientific and Managerial Implications}

Both scientists and practitioners will benefit from the results presented in this study, which derived and presented fields of action for the development of measures against food losses. Both in practical application and scientific analysis, this framework can be used as an orientation in the development of measures. For scientists, this study provides a scientifically-based foundation for developing measures to prevent food losses. This study may provide information in terms of the desired objective and direction of measures. For practitioners, the overview of identified literature in Table 2 holds practical relevance as it can be used as a reference guide to provide suggestions for concrete measures in specific fields of action.

\subsection{Future Research}

While analyzing the available evidence, this paper identified various areas that required further scientific investigation in order to improve the development and application of measures against food loss.

(1) What fields of action are best suited as objectives for specific types of companies within the network?

Based on the overview presented in this study, the question arises as to whether or not it is suitable for certain types of companies to focus on specific fields of action as objectives. Some authors address the position or function of the respective companies, but a structured examination of this question is missing. A systematic exploration of these interconnections could add value in practice.

(2) Are certain fields of action suitable as objectives for specific maturity levels in companies in terms of food loss management?

A further question arising from the results of this study is whether the use of certain fields of action as objectives is more suitable for companies at the beginning of their activities in food loss management versus those that have already reached a certain standard. A science-based investigation could create added value for companies; by examining such a hierarchy, businesses could then focus more specifically on suitable objectives, depending on their previous food loss management activities.

(3) How relevant are the fields of action assessed in practice and to what extent can they be compared with the frequency with which these fields of action are treated in science?

A comparison of the relevance of the fields of action found with the requirements in practice would be a relevant continuation of this study. Such research could also result in a need for further action by the scientific community in order to focus on and examine certain fields of action more closely.

(4) As objectives, which fields of action have a particularly strong effect on network partners in developing countries?

As described above, international food logistics has developed into a globally networked system that in many cases originates in developing countries. Based on this fact and derived from the results presented here, the question arises as to how partners in developing countries can be encouraged and supported. Partners in developing countries often are dependent on partners in industrialized countries. In many cases, this dependence means that issues, such as process efficiency and food loss management, are not on companies' agendas due to lack of available resources. The high relevance of the network cooperation field of action is indicative of this situation. In order to improve the 
situation of partners in developing countries in a sustainable manner and make them equal partners in international trade relations, researchers could investigate specific fields of action as objectives for the development of measures.

(5) When creating a uniform information base in a concrete value chain, which information is needed and which actor should provide it?

Many of the articles outlined above highlight the great importance of a consistent information base. Future research could analyze how such an information base could be designed across a network. This inquiry raises the question of which information would have to be provided by which actors. Further studies are needed into how to create incentives for actors to provide this information for the general benefit, even if the company cannot quantify this benefit for itself in the short term.

\subsection{Limitations}

In conducting this study, the researchers paid special attention to minimizing their individual influences. Nevertheless, this study faced some limitations, which are addressed in more detail below. Borrowing from Nitsche and Durach (2018), the approach pursued in this study combines practical and scientific statements in order to present the broadest picture possible. This research followed this approach by conducting a systematic literature analysis and by interviewing practitioners. However, the sample of practitioners was exceedingly small compared to the articles included from the systematic literature analysis. Consequently, the results are strongly influenced by the theoretical perspective. Regarding the systematic literature analysis, two databases were used, Business Source Complete (by EBSCO) and the Social Science Citation Index (SSCI) database (by Web of Science). The integration of further databases could have added further articles to the data collection, which would have created additional value. However, the selected databases contain many journals relevant to this topic, thus minimizing the risk of having missed relevant literature. Finally, a single researcher read the articles remaining after applying the inclusion and exclusion criteria, noting the criteria addressed in each one. This procedural step depended strongly on one person and could therefore have been influenced by their perspective. This issue was addressed by applying qualitative clustering, with two additional scientists involved in the process.

Funding: I acknowledge support by the German Research Foundation and the Open Access Publication Fund of TU Berlin.

Conflicts of Interest: The author declares no conflict of interest.

\section{References}

1. Food and Agriculture Organization. Food Outlook; Biannual Report on Global Food Markets, November 2017; FAO Trade and Markets Division: Rome, Italy, 2017; ISBN 978-92-5-130012-1.

2. Food and Agriculture Organization. The state of sood security and nutrition in the world. In Building Resilience for Food and Food Security; FAO: Rome, Italy, 2017; ISBN 978-92-5-109888-2.

3. United Nations. World Population Prospects: The 2017 Revision. Key Findings and Advance Tables. 2017. Available online: https://population.un.org/wpp/Publications/Files/WPP2017_KeyFindings.pdf (accessed on 7 March 2019).

4. Gustavsson, J.; Cederberg, C.; Sonesson, U. Global food losses and food waste—Extent, Causes and Prevention; FAO: Rome, Italy, 2011.

5. Hiç, C.; Pradhan, P.; Rybski, D.; Kropp, J.P. Food surplus and its climate burdens. Environ. Sci. Technol. 2016, 50, 4269-4277. [CrossRef]

6. United Nations. Transforming Our World: The 2030 Agenda for Sustainable Development 2015; United Nations: New York, NY, USA, 2015.

7. Nitsche, B.; Kleineidam, J.; Straube, F.; Meißner, M. Systematization and discussion of the current state of waste management in food supply chains: A systematic review. J. Jpn. Oper. Manag. Strategy 2018, 8, 1-17.

8. Straube, F. e-Logistik. Ganzheitliches Logistikmanagement; University of St. Gallen, habilitation thesis; Springer: Berlin, Germany, 2004; ISBN 3540208690. 
9. Nitsche, B.; Figiel, A. Zukunftstrends in der Lebensmittellogistik-Herausforderungen und Lösungsimpulse; Technical University of Berlin: Berlin, Germany, 2016.

10. Parfitt, J.; Barthel, M.; Macnaughton, S. Food waste within food supply chains: Quantification and potential for change to 2050. Philos. Trans. R. Soc. B Biol. Sci. 2010, 365, 3065-3081. [CrossRef]

11. Dani, S. Food Supply Chain Management and Logistics: From Farm to Fork; Kogan Page: London, UK, 2015; ISBN 9780749473648.

12. Food and Agriculture Organization of the United Nations. The State of Food and Agriculture; English, A., Ed.; Food and Agriculture Organization of the United Nations: Rome, Italy, 2019; ISBN 978-92-5-131789-1.

13. Kowalska, A. The issue of food losses and waste and its determinants. LogForum 2017, 13. [CrossRef]

14. HLPE. Food Losses and Waste in the Context of Sustainable Food Systems. A Report by the High Level Panel of Experts on Food Security and Nutrition of the Committee on World Food Security. 2014. Available online: http://www.fao.org/3/a-i3901e.pdf (accessed on 5 June 2020).

15. Papargyropoulou, E.; Lozano, R.; Steinberger, J.K.; Wright, N.; Ujang, Z.B. The food waste hierarchy as a framework for the management of food surplus and food waste. J. Clean. Prod. 2014, 76, 106-115. [CrossRef]

16. Nitsche, B.; Durach, C.F. Much discussed, little conceptualized: Supply chain volatility. Int. J. Phys. Distrib. Logist. Manag. 2018, 48, 866-886. [CrossRef]

17. Durach, C.F. A Theoretical and Practical Contribution to Supply Chain Robustness; Universitätsverlag der TU Berlin: Berlin, Germany, 2016.

18. Addisu Damtie, Y. The effect of shocks: An empirical analysis of Ethiopia. Interdiscip. Descr. Complex Syst. 2015, 13, 450-460. [CrossRef]

19. Faour-Klingbeil, D.; Murtada, M.; Kuri, V.; Todd, E.C.D. Understanding the routes of contamination of ready-to-eat vegetables in the Middle East. Food Control 2016, 62, 125-133. [CrossRef]

20. Sarpong, S. Traceability and supply chain complexity: Confronting the issues and concerns. Eur. Bus. Rev. 2014, 26, 271-284. [CrossRef]

21. Chuang, C.-H.; Lee, D.-H.; Chang, W.-J.; Weng, W.-C.; Shaikh, M.O.; Huang, C.-L. Real-Time monitoring via patch-type piezoelectric force sensors for internet of things based logistics. IEEE Sens. J. 2017, 17, 2498-2506. [CrossRef]

22. Kamble, S.S.; Gunasekaran, A.; Parekh, H.; Joshi, S. Modeling the internet of things adoption barriers in food retail supply chains. J. Retail. Consum. Serv. 2019, 48, 154-168. [CrossRef]

23. Brewster, C.; Roussaki, I.; Kalatzis, N.; Doolin, K.; Ellis, K. IoT in agriculture: Designing a Europe-wide large-scale pilot. IEEE Commun. Mag. 2017, 55, 26-33. [CrossRef]

24. Borit, M.; Santos, J. Getting traceability right, from fish to advanced bio-technological products: A review of legislation. J. Clean. Prod. 2015, 104, 13-22. [CrossRef]

25. Xiao, X.; He, Q.; Li, Z.; Antoce, A.O.; Zhang, X. Improving traceability and transparency of table grapes cold chain logistics by integrating WSN and correlation analysis. Food Control 2017, 73, 1556-1563. [CrossRef]

26. Chaudhuri, A.; Dukovska-Popovska, I.; Subramanian, N.; Chan, H.K.; Bai, R. Decision-Making in cold chain logistics using data analytics: A literature review. Int. J. Logist. Manag. 2018, 29, 839-861. [CrossRef]

27. Pinior, B.; Conraths, F.J.; Petersen, B.; Selhorst, T. Decision support for risks managers in the case of deliberate food contamination: The dairy industry as an example. Omega Int. J. Manag. Sci. 2015, 53, 41-48. [CrossRef]

28. Vlachos, I. Applying lean thinking in the food supply chains: A case study. Prod. Plan. Control 2015, 26, 1351-1367. [CrossRef]

29. Powell, D.; Lundeby, S.; Chabada, L.; Dreyer, H. Lean six sigma and environmental sustainability: The case of a Norwegian dairy producer. Int. J. Lean Six Sigma 2017, 8, 53-64. [CrossRef]

30. Colgan, C.; Adam, G.; Topolansky, F. Why try Lean? A Northumbrian farm case study. Int. J. Agric. Manag. 2013, 2, 170. [CrossRef]

31. Azuara, G.; Luis Tornos, J.; Luis Salazar, J. Improving RFID traceability systems with verifiable quality. Ind. Manag. Data Syst. 2012, 112, 340-359. [CrossRef]

32. Negi, S.; Anand, N. Wholesalers perspectives on mango supply chain efficiency in India. J. Agribus. Dev. Emerg. Econ. 2019, 9, 175-200. [CrossRef]

33. Chelbi, A.; Aït-Kadi, D.; Radhoui, M. An integrated production and maintenance model for one failure prone machine-finite capacity buffer system for perishable products with constant demand. Int. J. Prod. Res. 2008, 46, 5427-5440. [CrossRef] 
34. Laux, C.M.; Mosher, G.A.; Hurburgh, C.R. Application of quality management systems to grain handling: An inventory management case study. Appl. Eng. Agric. 2015, 313-321. [CrossRef]

35. Lau, H.; Nakandala, D.; Shum, P.K. A business process decision model for fresh-food supplier evaluation. Bus. Process Manag. J. 2018, 24, 716-744. [CrossRef]

36. Wilcock, A.E.; Boys, K.A. Improving quality management: ISO 9001 benefits for agrifood firms. J. Agribus. Dev. Emerg. Econ. 2017, 7, 2-20. [CrossRef]

37. Mor, R.S.; Bhardwaj, A.; Singh, S. Benchmarking the interactions among performance indicators in dairy supply chain. Benchmarking Int. J. 2018, 25, 3858-3881. [CrossRef]

38. Tsang, Y.P.; Choy, K.L.; Wu, C.H.; Ho, G.T.S.; Lam, H.Y.; Tang, V. An intelligent model for assuring food quality in managing a multi-temperature food distribution centre. Food Control 2018, 90, 81-97. [CrossRef]

39. Vanderroost, M.; Ragaert, P.; Verwaeren, J.; De Meulenaer, B.; De Baets, B.; Devlieghere, F. The digitization of a food package's life cycle: Existing and emerging computer systems in the logistics and post-logistics phase. Comput. Ind. 2017, 87, 15-30. [CrossRef]

40. Akkas, A.; Gaur, V.; Simchi-Levi, D. Drivers of product expiration in consumer packaged goods retailing. Manag. Sci. 2018, 65. [CrossRef]

41. Wikström, F.; Verghese, K.; Auras, R.; Olsson, A.; Williams, H.; Wever, R.; Grönman, K.; Kvalvåg Pettersen, M.; Møller, H.; Soukka, R. Packaging strategies that save food: A research agenda for 2030. J. Ind. Ecol. 2019, 23, 532-540. [CrossRef]

42. Molina-Besch, K.; Wikström, F.; Williams, H. The environmental impact of packaging in food supply chains-Does life cycle assessment of food provide the full picture? Int. J. Life Cycle Assess. 2019, 24, 37-50. [CrossRef]

43. Hu, H.; Zhang, Y.; Zhen, L. A two-stage decomposition method on fresh product distribution problem. Int. J. Prod. Res. 2017, 55, 4729-4752. [CrossRef]

44. Caixeta-Filho, J.V. Losses in the transportation of fruits and vegetables: A Brazilian case study. Int. J. Logist. Res. Appl. 1999, 2, 325-341. [CrossRef]

45. Bortolini, M.; Faccio, M.; Ferrari, E.; Gamberi, M.; Pilati, F. Fresh food sustainable distribution: Cost, delivery time and carbon footprint three-objective optimization. J. Food Eng. 2016, 174, 56-67. [CrossRef]

46. Mvumi, B.; Matsikira, L.T.; Mutambara, J. The banana postharvest value chain analysis in Zimbabwe. Br. Food J. 2016, 118, 272-285. [CrossRef]

47. Leśniewski, P.; Bartoszewicz, A. LQ optimal sliding mode control of periodic review perishable inventories with transportation losses. Math. Probl. Eng. 2013, 2013, 1-9. [CrossRef]

48. Garbaba, C.A.; Denboba, L.G.; Mendesil, E.; Ocho, F.L.; Hensel, O. Actors' post-harvest maize handling practices and allied mycoflora epidemiology in southwestern Ethiopia: Potential for mycotoxin-producing fungi management. J. Appl. Bot. Food Qual. 2018, 91, 237-248. [CrossRef]

49. Facchini, F.; Pascale, G.; de Faccilongo, N. Pallet picking strategy in food collecting center. Appl. Sci. Basel 2018, 8, 1503. [CrossRef]

50. Gong, W.; Li, D.; Liu, X.; Yue, J.; Fu, Z. Improved two-grade delayed particle swarm optimisation (TGDPSO) for inventory facility location for perishable food distribution centres in Beijing. N. Z. J. Agric. Res. 2007, 50, 771-779. [CrossRef]

51. Orjuela Castro, J.A.; Adarme Jaimes, W. Dynamic impact of the structure of the supply chain of perishable foods on logistics performance and food security. J. Ind. Eng. Manag. JIEM 2017, 10, 687. [CrossRef]

52. Brunelle, T.; Coat, M.; Viguié, V. Demand-Side mitigation options of the agricultural sector: Potential, barriers and ways forward. OCL Oilseeds Fats Crop. Lipids 2017, 24, D104. [CrossRef]

53. Cristóbal, J.; Castellani, V.; Manfredi, S.; Sala, S. Prioritizing and optimizing sustainable measures for food waste prevention and management. Waste Manag. 2018, 72, 3-16. [CrossRef] [PubMed]

54. Rijpkema, W.; Rossi, R.; van der Vorst, J. Effective sourcing strategies for perishable product supply chains. Int. J. Phys. Distrib. Logist. Manag. 2014, 44, 494-510. [CrossRef]

55. Wu, L.; Hu, Q.; Wang, J.; Zhu, D. Empirical analysis of the main factors influencing rice harvest losses based on sampling survey data of ten provinces in China. China Agric. Econ. Rev. 2017, 9, 287-302. [CrossRef]

56. Brüntrup, M.; Schwarz, F.; Absmayr, T.; Dylla, J.; Eckhard, F.; Remke, K.; Sternisko, K. Nucleus-Outgrower schemes as an alternative to traditional smallholder agriculture in Tanzania-Strengths, weaknesses and policy requirements. Food Secur. 2018, 10, 807-826. [CrossRef] 
57. Singh, A.K.; Subramanian, N.; Pawar, K.S.; Bai, R. Cold chain configuration design: Location-Allocation decision-making using coordination, value deterioration, and big data approximation. Ann. Oper. Res. 2018, 270, 433-457. [CrossRef]

58. Raab, V.; Petersen, B.; Kreyenschmidt, J. Temperature monitoring in meat supply chains. Br. Food J. 2011, 113, 1267-1289. [CrossRef]

59. Bakhtavar, M.A.; Afzal, I.; Basra, S.M.A.; Wahid, A. Implementing the 'dry chain' during storage reduces losses and maintains quality of maize grain. Food Secur. 2019, 11, 345-357. [CrossRef]

60. Martindale, W.; Schiebel, W. The impact of food preservation on food waste. Br. Food J. 2017, 119, $2510-2518$. [CrossRef]

61. Allen, S.J.; Schuster, E.W. Controlling the risk for an agricultural harvest. M $\mathcal{E}$ SOM 2004, 6, $225-236$. [CrossRef]

62. Kaya, O.; Ghahroodi, S.R. Inventory control and pricing for perishable products under age and price dependent stochastic demand. Math. Methods Oper. Res. 2018, 88,1-35. [CrossRef]

63. Aggarwal, S.; Srivastava, M.K. Towards a grounded view of collaboration in Indian agri-food supply chains. Br. Food J. 2016, 118, 1085-1106. [CrossRef]

64. Alberti, F.G.; Belfanti, F. Creating shared value and clusters. Compet. Rev. 2019, 29, 39-60. [CrossRef]

65. Kouwenhoven, G.; Reddy Nalla, V.; Lossonczy von Losoncz, T.; Ifamr, I. Creating sustainable businesses by reducing food waste: A value chain framework for eliminating inefficiencies. Int. Food Agribus. Manag. Rev. 2012, 15, 119-138.

66. Devin, B.; Richards, C. Food waste, power, and corporate social responsibility in the Australian food supply chain. J. Bus. Ethics 2018, 150, 199-210. [CrossRef]

67. Alarcon, P.; Fèvre, E.M.; Murungi, M.K.; Muinde, P.; Akoko, J.; Dominguez-Salas, P.; Kiambi, S.; Ahmed, S.; Häsler, B.; Rushton, J. Mapping of beef, sheep and goat food systems in Nairobi-A framework for policy making and the identification of structural vulnerabilities and deficiencies. Agric. Syst. 2017, 152, 1-17. [CrossRef]

68. Markelova, H.; Mwangi, E. Collective action for smallholder market access: Evidence and implications for Africa. Rev. Policy Res. 2010, 27, 621-640. [CrossRef]

69. Tsuchiya, K.; Hara, Y.; Thaitakoo, D. Linking food and land systems for sustainable peri-urban agriculture in Bangkok metropolitan region. Landsc. Urban Plan. 2015, 143, 192-204. [CrossRef]

70. Alamar, M.D.C.; Falagán, N.; Aktas, E.; Terry, L.A. Minimising food waste: A call for multidisciplinary research. J. Sci. Food Agric. 2018, 98, 8-11. [CrossRef]

71. Al-Madbouh, S.; Al-Khatib, I.A.; Al-Sari, M.I.; Salahat, J.I.; Jararaa, B.Y.A.; Ribbe, L. Socioeconomic, agricultural, and individual factors influencing farmers' perceptions and willingness of compost production and use: An evidence from Wadi al-Far'a watershed-Palestine. Environ. Monit. Assess. 2019, 191, 209. [CrossRef]

72. Pan, S.; Giannikas, V.; Han, Y.; Grover-Silva, E.; Qiao, B. Using customer-related data to enhance e-grocery home delivery. Industrial Manag. Data Syst. 2017, 117, 1917-1933. [CrossRef]

(C) 2020 by the author. Licensee MDPI, Basel, Switzerland. This article is an open access article distributed under the terms and conditions of the Creative Commons Attribution (CC BY) license (http://creativecommons.org/licenses/by/4.0/). 